\title{
Efektivitas Pembelajaran Daring terhadap Penguatan Budaya Literasi Membaca Siswa Kelas V di MI Madani Alauddin Kabupaten Gowa
}

\author{
Andi Hasrianti ${ }^{1}$ \\ Umar Sulaiman ${ }^{2}$ \\ ${ }^{12}$ Universitas Islam Negeri Alauddin Makassar
}

andi.hasrianti@uin-alauddin.ac.id

\begin{abstract}
Abstrak
Penelitian ini bertujuan untuk mengetahui: 1) Implemntasi pembelajaran daring pada siswa kelas V di MI Madani Alauddin, Kabupaten Gowa, 2) Gambaran budaya literasi membaca pada siswa kelas V di MI Madani Alauddin, Kabupaten Gowa, 3) Efektivitas pembelajaran daring terhadap penguatan budaya literasi membaca siswa kelas V di MI Madani Alauddin, Kabupaten Gowa. Jenis penelitian yang digunakan adalah ex-post facto. Partisipan penelitian ini adalah seluruh peserta didik kelas $\mathrm{V}$ di MI Madani Alauddin Kabupaten Gowa yang berjumlah 41 orang. Adapun instrumen yang digunakan pada penelitian ini adalah angket dan tes. Teknik anlisis data yang digunakan adalah statistik deskriptif dan statistik inferensial. Berdasarkan hasil analisis data dengan menggunakan statistik deskriptif diperoleh skor rata-rata peserta didik sebesar 50 untuk pengisian kuesioner tentang implementasi pembelajaran daring dan diperoleh nilai rata-rata peserta didik sebesar 86 untuk tes keterampilan membaca. Hasil analisis statistik inferensial diperoleh t_(hitung) $>$ dari t_(tabel ) $(8,17>1,68)$ yang berarti bahwa implementasi pembelajaran daring efektif terhadap penguatan budaya literasi membaca pada peserta didik kelas V di MI Madani Aluaddin Kabupaten Gowa. Implikasi dalam penelitian ini 1) Implementasi pembelajaran daring efektif terhadap penguatan budaya literasi membaca peserta didik kelas V di MI Madani Alauddin Kabupaten Gowa 2) Menjadi dasar untuk penelitian berikutnya tentang literasi.
\end{abstract}

Kata kunci: efektivitas, pembelajaran daring, budaya literasi membaca

\section{Pendahuluan}

Seiring dengan masuknya era global pada abad ke-21, peran pendidikan semakin penting dalam rangka menghadapi tuntutan zaman yang penuh persaingan pada semua aspek bidang kehidupan. Saat ini hampir tidak ada celah bagi bangsa yang kualitas sumber daya manusianya rendah untuk dapat maju dan berkembang. Sebaliknya, bangsa tersebut secara perlahan akan tenggelam dari peta perceturan dunia, seberapapun besarnya jumlah penduduk dan luas yang dimilikinya (Winarti, 2018). Pendidikan pula memiliki tanggung jawab untuk mengembangkan karakter anak bangsa, karena salah satu tugas dari pendidikan yaitu untuk mewariskan nilai-nilai luhur bangsa. Walaupun demikian kita harus terbuka untuk melakukan perubahan, menyesuaikan dengan kemajuan dan perkembangan dunia, sehingga kita tidak sempit memandang dunia dengan globalisasinya (Hamdani \& Priatna, 2020; Baety \& Munandar, 2021).

Pendidikan merupakan pendewasaan peserta didik agar dapat mengembangkan bakat, potensi, dan keterampilan yang dimilikinya dalam menjalani kehidupan (Fatoni, 2020). Oleh karena itu, pendidikan didesain untuk memberikan pemahaman yang dapat meningkatkan prestesi belajar sisiwa. Pendidikan juga dapat menjadi penentu dari nilai dan kualitas hidup individu (Winarti \& Purwanti, 2014). Dilihat dari besarnya peran 
pendidikan dalam kehidupan, ada baiknya pendidikan di negara ini dapat lebih dikembangakan secara maksimal dan memberikan berbagai manfaat pada setiap individu (Yulianto \& Nugraheni, 2021). Perkembangan pada abad ini menuntut dunia pendidikan untuk mengubah konsep dalam berfikir, masa depan yang $\mathrm{k}$ memiliki implikasi luas dan mendalam terhadap berbagai rancangan pengajaran dan teknik pembelajaran, maka perlu guru menyadari bahwa del maupun startegi pembelajaran yang konvensional tidak akan cukup membantu peserta didik.

Indonesia saat ini tengah dihadapkan dengan tantangan pandemi Covid-19, pemeritnah telah menghimbau kepada masyarakat Indonesia untuk tetap di rumah saja, melihat efek penularan dari virus ini sangat cepat dan berdampak buruk pada kesehatan bahkan bisa menyebabkan kematian (Masrul et al., 2020; Harirah \& Rizaldi, 2020). Kemunculan pandemi Covid-19 mempengaruhi segala sektor kehidupan manusia, termasuk di dalamnya sektor pendidikan yang kini mengharuskan pembelajaran yang semula dilakukan secara tatap muka beralih meniadi pembelaiaran non tatap muka (Gusty et al., 2020; Pakpahan \& Fitriani, 2020; Abidin et al., 2020). Pembelajaran daring (dalam jaringan) dipilih meniadi alternatif vang tepat untuk menggati pembelajaran langsung atau tatap muka (Bhagaskara et al., 2021; Napitupulu, 2020).

Pembelajaran daring merupakan pemanfaatan jaringan internet dalam proses pembelajaran, pembelajaran daring adalah pembelajaran dalam jaringan untuk menjangkau kelompok target yang masif serta luas, sehingga pembelajaran daring dapat terlaksana dimana saja serta diikuti secara gratis atau berbayar (Ratna, 2021; Isman, 2016; Astini, 2020; Fauzi \& Khusuma, 2020). Selain itu pembelajaran daring memanfaatkan jaringan internet dalam proses pembelajaran dan memberikan metode pembelajaran yang efektif. Pembelajaran daring memiliki manfaat seperti membangun komunikasi serta diskusi anatara guru dengan peserta didik, peserta didik saling berinteraksi dan berdiskusi dengan satu dan lainnya, memudahkan peserta didik berinteraksi dengan guru dan orang tua, guru dapat dengan mudah menyampaiakan materi terhadap peserta didik berupa gambar, video, maupun audio yang bisa diunduh oleh orang tua secara langsung dan mempermudah guru membuat materi dimana saja dan kapan saja (Ayuni et al., 2020; Nurkolis \& Muhdi, 2020).

Implementasi pembelajaran secara daring ini paling banyak dilaksanakan dengan menggunakan aplikasi WhatsApp dengan pertimbangan rata-rata guru dan siswa atau orang tua siswa memiliki aplikasi ini pada gadget masing-masing (Dewi, 2020; Naserly, 2020; Maulida et al., 2021). Aplikasi ini memiliki fitur WhatsApp Group sehingga guru dan siswa dapat berdiskusi serta saling berbagi dokumen (Prasetyo \& Zulela, 2021; Riadil, 2020). Guru memanfaatkan fitur ini untuk membagi dokumen materi pembelajaran dan tugas bagi siswa, kemudian siswa akan mengirimkan tugas yang telah mereka selesaikan melalui grup ini pula. Hal yang perlu diperhatikan adalah pemberian tugas disertai pemantauan dan pendampingan oleh guru. Langkah-langakah yang harus dilakukan adalah guru meminta bantuan orang tua maupun kakak siswa sebagai narahubung dengan pemberitahuan lebih dahulu melaui WhatsApp Group. Selain itu, perlu disertakan pula koordinasi dan interaksi anatara guru dan orang tua siswa berupa video call maupun foto dokumentasi kegiatan belajar siswa di rumah sebgaia bentuk laporan bahwa siswa benar-benar melaksanakan pembelajaran di rumah.

Kemdikbud menyebut pembelajaran teknologi bagi anak-anak adalah hal yang jauh lebih mudah. Apalagi, saat ini sekolah berhadapan dengan generasi Z. Generasi yang sangat lekat dan akrab dengan gawai atau teknologi digital. Karena itu, sebenarnya anakanak lebih mudah beradaptasi untuk menggunakan teknologi. Adaptasi teknologilah vang kemudian mendorong anak-anak untuk mudah bermigrasi ke era industri 4.0 (Hamdani \& Priatna, 2020). Meskipun diterapkannya pembelajaran daring peserta didik juga harus tetap diperkenalkan dengan literasi, terutama literasi membaca. Jangan sampai hadirnva pembelaiaran vang serba online menggeser budaya literasi pada peserta didik (Indriani \& Yemmardotillah, 2021).

Literasi merupakan keberaksaraan yang meliputi kemampuan membaca dan menulis, budaya literasi sendiri dimksudkan untuk melakukan kebiasaan untuk berpikir yang dapat diikuti dengan proses membaca, menulis dan pada akhirnya apa vang telah dilakukan dalam proses kegiatan tersebut dapat menciptakan sebuah karya (Subandiyah, 
2017; Joyo, 2018; Numertayasa et al., 2020). Literasi mempunyai peran penting dalam mencapai tujuan pembelajaran. Literasi berkaitan dengan keterampilan berbahasa, dimana literasi merupakan kemampuan membaca dan menulis (Murray, 2021; Truelove, 2020; Opoku-Amankwa \& Brew-Hammond, 2011). Aktivitas literasi dapat diartikan sebagai aktivitas berkomunikasi dan berpikir dalam proses pembelajaran (Mardliyah, 2019; Alfian, 2018).

Di kanca internasional capaian kemampuan literasi peserta didik Indonesia masuk pada kategori rendah (Argina, 2017). Hal ini dibuktikan oleh hasil studi Programme for Internasional Student Assessment (PISA) tanun 2000, 2003, 2006, 2009, dan 2012 secara berurutan adalah 393, 395, 395, 383, dan 382 yang menunjukan bahwa literasi peserta didik Indonesia masih sangat rendah karena di bawah rata-rata skor internasional (Pakpahan, 2016; Hewi \& Shaleh, 2020; Hawa \& Putra, 2018). Melihat data ini, tentu menjadi acuan kita guna menghidupkan kembali semangat literasi pada peserta didik di Indonesia, apalagi dengan kondisi sekarang yang mengharuskan peserta didik belajar di rumah. Semangat literasi itu mungkin akan hilang, ditambah dengan kurangnya literatur atau media yang menarik minat peserta didik untuk membaca atau melakukan kegiatan literasi lainnya. Selain itu, suasana pembelajaran langsung (offline) di sekolah masih dirasa lebih menarik dibandingkan dengan pembelajaran daring (online) yang dilakukan di rumah masing-masing (Sanjaya, 2020; Dini, 2021). Oleh karena itu pendidik dan orang tua diharapkan mampu menciptakan hal-hal yang menarik minat belajar online peserta didik, misalya menciptakan lingkungan belajaran yang positif, membangun komunitas belajar, memberikan umpan balik yang konsisten secara tepat waktu, dan menggunakan teknologi yang tepat untuk mengirimkan konten atau video pembelajaran yang tepat.

Berdasarakan penjelasan di atas maka penulis akan mendeskripsikan masalahmasalah yang terjadi di lingkungan sekolah terkait dengan penerapan pembelajaran daring di masa pandemi Covid 19 ini. Situasi pembelajaran berubah total dari yang awalnya guru dan peserta didik bertemu langsung di ruagan kelas, sekarang beralih menjadi pembelajaran daring atau lewat layar komputer, HP, ataupun Televisi. Budaya yang biasanya dilakukan sebelum atau sesudah pembelajaran mulai bergeser atau hampir tidak dilaksanakan karena dibatasi jarak antara guru dan peserta didik itu sendiri, seperti contoh kegiatan membaca lima menit sebelum dan sesudah pembelajaran hampir tidak pernah dilakukan selama pandemi ini sehingga minat baca dan budaya literasi peserta didik di rumah perlu dipertanyakan.

Berdasarkan beberapa masalah yang muncul di atas, penulis merumuskan masalah pada penelitian ini sebagai berikut:

1. Bagaimana implementasi pembelajaran daring pada siswa Kelas V di MI Madani Alauddin Kabupaten Gowa?

2. Bagaimana gambaran budaya literasi membaca siswa kelas V di MI Madani Alauddin Kabupaten Gowa?

3. Apakah pembelajaran daring efektif terhadap penguatan budaya literasi membaca pada siswa kelas V di MI Madani Alauddin Kabupaten Gowa?

\section{Metode}

Jenis penelitian yang digunakan dalam penelitian ini adalah penelitian Ex-post facto. Lokasi penelitian ini akan dilaksanakan di Madrasah Ibtidaiyah (MI) Madani Alauddin Kabupaten Gowa. Teknik sampel yang digunakan dalam penelitian ini adalah Sampling Purposive. Adapun sampel dalam penelitian ini adalah seluruh siswa kelas V di MI Madani Alauddin Kabupaten Gowa terdiri dari 22 orang peserta didik laki-laki dan 19 orang peserta didik perempuan sehingga jumlah sampel pada penelitian ini adalah 41 orang. Metode pengumpulan data memberi seperangkat pertanyaan atau pernyataan tertulis kepada responden untuk dijawab dan pengumpulan data dengan menggunakan tes dilakukan untuk mengumpulkan data yang berhubungan dengan pengetahuan responden yang berhubungan dengan masalah tingkat pengetahuan subyek atau variabel yang diteliti. Dalam penelitian ini peneliti menggunakan tes untuk mengetahui keterampilan 
membaca peserta didik, adapun tes yang di gunakan yaitu berupa teks bacaan yang bersumber dari buku sekolah elektronik untuk kelas $\mathrm{V}$.

Instrumen pada penelitian ini adalah: angket dan tes berupa teks bacaan yang bersumber dari buku sekolah elektronik untuk kelas V. Analisis data yang digunakan dalam penelitian ini adalah teknik statistik, teknik statistik penelitian ini yaitu statistik deskriptif dan statistik inferensial.

Dalam statistik inferensial penulis menggunakan rumus statistik regresi linear sederhana dengan rumus sebagai berikut:

Dengan :

$$
\hat{Y}=a+b X
$$

$$
\begin{gathered}
\mathrm{a}=\frac{\sum Y-\sum X}{n} \\
\mathrm{~b}=\frac{N \sum X Y-\left(\sum X\right)\left(\sum Y\right)}{N \sum X^{2}-\left(\sum X\right)^{2}}
\end{gathered}
$$

Dimana:

Jadi, untuk menentukan nilai a harus ditentukan nilai b terlebih dahulu.

$\hat{Y}$ : subjek dalam variabel dependen (terikat) di prediksikan

a: nilai konstanta harga $\mathrm{X}=0$

b:nilai arah sebagai penentu ramalan (prediksi) yang menunjukkan nilai peningkatan (+) atau nilai penurunan (-) variabel $Y$

$\mathrm{X}$ : subjek pada variabel independen (bebas) yang mempunyai nilai tertentu.

Kemudian untuk menilai seberapa besar efektivitas pembelajaran daring terhadap penguatan budaya literasi membaca pada peserta didik kelas V MI Madani Pao-Pao Kabupaten Gowa dapat di hitung dengan menentukan kooefesien dertimenasi.

$$
r_{x y}=\frac{n \sum x y-\left(\sum x\right)\left(\sum y\right)}{\sqrt{\left(n \times \sum X^{2}-\left(\left(\sum x\right)^{2}-\left(n \times \Sigma y^{2}-\left((\Sigma y)^{2}\right)\right.\right.\right.}}
$$

Untuk menguji signifikan efektivitas variabel X terhadap variabel Y dapat dihitung dengan langkah-langkah sebagai berikut:

$$
t_{\text {hitung }}=\frac{r x y \sqrt{n-2}}{\sqrt{1-r x y^{2}}}
$$




\section{Hasil Penelitian}

a. Implementasi Pembelajaran Daring pada siswa Kelas V di MI Madani Alauddin Kabupaten Gowa

Berdasarkan hasil penelitian yang dilakukan di MI Madani Alauddin Kabupaten Gowa, berikut hasil penilaian yang dilakukan melalui instrumen angket. Diolah dari hasil angket pembelajaran daring siswa kelas V MI Madani Alauddin Kabupaten Gowa. Berikut ini disajikan distribusi skor responden pada tabel 1 di bawah.

Tabel 1. Distribusi Frekuensi Skor Responden

\begin{tabular}{ccc}
\hline Interval & Frekuensi & Persentase \\
\hline $54-55$ & 11 & $26 \%$ \\
$52-53$ & 2 & $6 \%$ \\
$50-51$ & 6 & $14 \%$ \\
$48-49$ & 13 & $31 \%$ \\
$46-47$ & 6 & $14 \%$ \\
$44-45$ & 2 & $6 \%$ \\
$42-43$ & 1 & $3 \%$ \\
& & \\
Jumlah & 41 & $100 \%$ \\
\hline
\end{tabular}

Berdasarkan tabel 1 di atas, pengisian angket implementasi pembelajaran daring di kelas V Menunjukkan skor yang diperoleh siswa bervariasi mulai dari skor terendah 42 dan skor tertinggi mencapai 55. Dengan rentang skor 12 menunjukkan implementasi pembelajaran daring pada siswa kelas V di MI Madani Alauddin Kabupaten Gowa.

b. Gambaran Budaya Literasi Membaca Siswa Kelas V di MI Madani Alauddin Kabupaten Gowa

Berdasarkan hasil penelitian yang telah dilakukan di MI Madani Alauddin Kabupaten Gowa mengenai variabel budaya literasi membaca siswa yang dilihat dengan cara mengukur tingkat keterampilan membaca siswa. Hasil perhitungan rata-rata nilai hasil tes keterampilan membaca pada siswa kelas V MI Madani Alaudin Kabupaten Gowa adalah 86. Nilai yang dicapai siswa bervariasi mulai dari nilai 67 sampai nilai sangat tinggi 100. Rata-rata hasil tes keterampilan disajikan pada tabel 2 di bawah ini.

Tabel 2. Rata-rata Hasil Tes Keterampilan Membaca

\begin{tabular}{ccccc}
\hline No & Interval & Kategori & Frekuensi & Persentase \\
\hline 1 & $0-20$ & Sangat rendah & 0 & 0 \\
2 & $21-40$ & Rendah & 0 & 0 \\
3 & $41-60$ & Sedang & 0 & 0 \\
4 & $61-80$ & Tinggi & 9 & $21 \%$ \\
5 & $81-100$ & Sangat tinggi & 32 & $79 \%$ \\
& Jumlah & & 41 & $100 \%$ \\
\hline
\end{tabular}

Berdasarkan tabel diatas maka gambaran budaya literasi membaca siswa kelas V di MI Madani Alauddin Kabupaten Gowa dikatakan efektif dengan adanya budaya literasi di sekolah, ini terlihat dari 9 siswa pada kategori tinggi dan 32 siswa pada kategori sangat tinggi. 
c. Efektivitas pembelajaran Daring terhadap Penguatan Budaya Literasi Membaca Siswa Kelas V di MI Madani Alauddin Kabupaten Gowa

Data yang dianalisis dalam penelitian ini adalah data skor rata-rata hasil angket penilaian implementasi pembelajaran daring, sebanyak 41 data sebagai variabel X. Sementara untuk variabel Y merupakan hasil skor penialain keterampilan membaca siswa sebanyak 41 nilai. Diketahui bahwa skor $\sum X=2050, \sum Y=3548, \sum X^{2}=102946, \sum$ $Y^{2}=313736, \sum X Y=177531$. Selanjutnya hasil angka-angka tersebut akan diolah dan diuji secara statistik untuk melihat efektivitas variabel X (implementasi pembelajaran daring terhadap variabel Y (Budaya literasi membaca) dengan rumus regresi linear. Persamaan regresi hasil penelitian ini dapat dirumuskan sebagai berikut:

$$
\begin{gathered}
Y=a+b X \\
Y=(36)+(0,18) X
\end{gathered}
$$

Jika nilai variabel $X$ dianggap nol maka nilai $Y$ sebesar 0,18 dan apabila nilai $X$ berubah menjadi satu maka nilai Y akan naik. Dengan demikian dapat disimpulkan bahwa implementasi pembelajaran daring berpengaruh positif terhadap budaya literasi atau keterampilan membaca siswa kelas V di MI Madanin Alauddin Kabupaten Gowa.

Besarnya pengaruh variabel $\mathrm{X}$ implementasi pembelajaran daring terhadap variabel Y (budaya literasi membaca siswa) adalah sebesar 1,56 artinya jika koefesien regresi semakin mendekati angka 1 menunjukkan hubungan antara variabel semakin kuat. Sedangkan nilai signifikan pengaruh variabel X terhadap variabel Y yaitu $t_{\text {tabel }}$ sebesar 1,68 Kemudian kaidah pengujian ditentukan dengan ketentuan jika $t_{\text {hitung }}>$ dari $t_{\text {tabel }}$ maka hipotesis penelitian diterima dan jika $t_{\text {hitung }}<$ dari $t_{\text {tabel }}$ maka hipotesis penelitian ditolak. Dengan demikian dalam penelitian ini $t_{\text {hitung }}>$ dari $t_{\text {tabel }}(8,17>1,68)$ yang berarti bahwa implementasi pembelajaran daring efektif terhadap penguatan budaya literasi membaca siswa kelas V di MI Madani Alauddin Kabupaten Gowa.

\section{Pembahasan}

Implementasi pembelajaran daring di MI Madani Alauddin Kabupaten Gowa khususnya di kelas $\mathrm{V}$ terlihat sangat baik, hal ini dikarenakan adanya antusias dan kerja sama yang baik antara pendidik dan orang tua pada saat proses pembelajarn berlangsung. Hadirrya pembelajaran daring ini menjadi alternatif yang tepat untuk mengganti proses pembelajaran langsung atau tatap muka di MI Madani Alauddin.

Ibu Andi Kurniati, SS., S.Pd.i., M.Pd selaku wali kelas V di MI Madani memiliki metode dan cara tersendiri dalam menerapkan pembelajaran berbasis daring dengan menarik pada peserta didiknya. Berbeda dengan guru-guru lain Ibu Andi menggunakan aplikasi Epmodo sebagai aplikasi pengganti Zoom atau Google Meet untuk mengajar daring, dan diselingi dengan aplikasi WhatsApp. Lewat apikasi tersebut peserta didik bisa mengisi daftar hadir, membaca, mendengarkan materi, dan mengirim tugas.

Kaitannya antara implementasi pembelajaran daring dengan penguatan budaya literasi peserta didik kelas V di MI Madani Alauddin Kabupaten Gowa adalah untuk melihat bagaimana pengaruh atau efek dari penerapan pembelajaran yang berbasis dalam jaringan (daring) pada penguatan budaya literasi membaca peserta didik yang dilakukan di rumah masing-masing. Budaya literasi yang biasa dilaukan di sekolah adalah pembiasaan kegiatan membaca 15 menit yang di lakukan setiap hari di awal, tengah atau menjelang akhir pelajaran, adanya kegiatan literasi seluruh warga sekolah dilaksanakan 
dua kali dalam seminggu, memiliki sarana berliterasi meliputi, ada bahan kaya teks yang terpampang di tiap kelas ada area lain di sekolah, tersedianya buku bacaan non pelajaran dan buku pelajaran yang di manfaatkan untuk kegiatan literasi, adanya perpustakaan, tersedianya sudut baca di tiap kelas dan area baca yang nyaman.

Hasil analisis deskriptif diperoleh implementasi pembelajaran daring peserta didik kelas V di MI Madani Alauddin Kabupaten Gowa dengan jumlah peserta didik 41 orang melalui data hasil pengisian angket mendapatkan skor yang bervariasi, mulai dari skor terendah 42 sampai skor tertinggi mencapai 55, skor rata-rata sebesar 50. Hasil ini menunjukkan bahwa implementasi pembelajaran daring peserta didik kelas V di MI Madani Alauddin Kabupaten Gowa efektif, dikatakan efektif pembelajaran daring menajadi alternatif yang tepat, kegiatan budaya literasi tetap berjalan dengan maksimal meskipun dilakukan di rumah masing-masing, hadirnya pembelajaran daring juga menambah wawasan peserta didik tentang teknologi dan informasi, peserta didik tidak hanya membaca melalui media cetak saja, tapi bisa juga dengan media elektronik berupa HP dan lain-lain.

Hasil tes keterampilan membaca peserta didik kelas V di MI Madani Alauddin Kabupaten Gowa mendapatkan nilai rata-rata sebesar 86, hal ini menunjukkan bahwa keterampilan membaca peserta didik berada pada kategori sangat tinggi, intonasi dalam membaca sangat baik, benar dan tepat, lafal dalam membaca sangat baik, benar dan tepat. Kedua aspek tersebut tercapai dan menjadi dasar dalam menilai keterampilan membaca di MI Madani Alauddin Kabupaten Gowa.

Hasil penelitian dengan statistik inferensial, dari tabel perhitungan koofisien regresi sederhana diketahui $\sum X=2050, \sum Y=3548, \sum X^{2}=102946, \sum Y^{2}=31336, \sum X Y=177531$, selanjutnya hasil angka-angka tersebut akan diolah dan di uji untuk melihat efektivitas variabel $\mathrm{x}$ terhadap variabel $\mathrm{y}$ dengan rumus regresi linear $\mathrm{y}=\mathrm{a}+\mathrm{Bx}$ hasil dengan penjumlahan tersebut yaitu $\mathrm{y}=(36)+(0,18) \mathrm{x}$, jika nilai variabel $\mathrm{x}$ dianggap nol maka nilai y sebesar 0,18 dan apabila nilai $\mathrm{x}$ berubah menjadi satu maka nilai y akan naik dengan demikian disimpulkan bahwa implementasi pembelajaran daring berpengaruh positif terhadap budaya literasi membaca. Untuk menilai seberapa besar efektivitas implementasi pembelajaran daring terhadap budaya literasi membaca peserta didik di hitung dengan menentukan koofesien dertimenasi, hasilnya sebesar 1,56, artinya semakin mendekati angka 1 menunjukkan hubungan antara variabel semakin kuat. Untuk menguji signifikan variabel $x$ terhadap variabel y dapat dihitung dengan menggunakan $t$ hitung, hasil dari t hitung sebesar 8,17, dengan demikian dapat diketahui $t_{\text {tabel }}$ sebesar 1,68 Kemudian kaidah pengujian ditentukan dengan ketentuan jika $t_{\text {hitung }}>$ dari $t_{\text {tabel }}$ maka hipotesis penelitian diterima dan jika $t_{\text {hitung }}<$ dari $t_{\text {tabel }}$ maka hipotesis penelitian ditolak $t_{\text {hitung }}>$ dari $t_{\text {tabel }}(8,17>1,68)$ yang berarti bahwa implementasi pembelajaran daring (full daring) efektif terhadap penguatan budaya literasi membaca peserta didik kelas V di MI Madani Alauddin Kabupaten Gowa. 


\section{Simpulan}

Berdasarkan nilai analisis pembahasan tentang efektivitas pembelajaran daring terhadap penguatan budaya literasi peserta didik kelas V di MI Madani Alauddin Kabupaten Gowamaka dapat disimpulkan sebagai berikut:

1. Skor implementasi pembelajaran daring terhadap penguatan budaya literasi peserta didik kelas V di MI Madani Alauddin Kabupaten Gowa rata-rata sebesar 50. Hal ini menunjukkan bahwa implementasi pembelajaran daring efektif.

2. Nilai keterampilan membaca peserta didik kelas V di MI Madani Alauddin Kabupaten Gowa rata-rata sebesar 86 . Hal ini menunjukkan bahwa budaya literasi membaca berada pada kategori sangat tinggi terlihat dari hasil tes keterampilan membaca peserta didik.

3. Implementasi pembelajaran daring efektif terhadap penguatan budaya literasi peserta didik kelas V di MI Madani Alauddin Kabupaten Gowa. Hal ini menujukkan nilai $t_{\text {hitung }}>$ dari $t_{\text {tabel }}(8,17>1,68)$ yang berarti bahwa Implementasi pembelajaran daring (full online) efektif terhadap penguatan budaya literasi peserta didik kelas $\mathrm{V}$ di MI Madani Alauddin Kabupaten Gowa.

\section{Ucapan Terima Kasih}

\section{Daftar Pustaka}

Abidin, Z., Hudaya, A., \& Anjani, D. (2020). Efektivitas pembelajaran jarak jauh pada masa pandemi covid-19. Research and Development Journal of Education, 1(1), 131-146.

Alfin, J. (2018). Membangun Budaya Literasi Dalam Pembelajaran Bahasa Indonesia Menghadapi Era Revolusi Industri 4.0. PENTAS: Pendidikan Bahasa dan Sastra Indonesia, 4(2), 60-66.

Argina, A. W., Mitra, D., Ijabah, N., \& Setiawan, R. (2017). Indonesian PISA result: What factors and what should be fixed? In Proceedings Education and Language International Conference (Vol. 1, No. 1).

Astini, N. K. S. (2020). Pemanfaatan teknologi informasi dalam pembelajaran tingkat sekolah dasar pada masa pandemi covid-19. Lampuhyang, 11(2), 13-25.

Ayuni, D., Marini, T., Fauziddin, M., \& Pahrul, Y. (2020). Kesiapan guru TK menghadapi pembelajaran daring masa pandemi COVID-19. Jurnal Obsesi: Jurnal Pendidikan Anak Usia Dini, 5(1), 414-421.

Baety, D. N., \& Munandar, D. R. (2021). Analisis Efektifitas Pembelajaran Daring Dalam Menghadapi Wabah Pandemi Covid-19. Edukatif: Jurnal Ilmu Pendidikan, 3(3), 880989.

Bhagaskara, A. E., Afifah, E. N., \& Putra, E. M. (2021). Pembelajaran Dalam Jaringan (DARING) Berbasis WhatsApp Di SD Yapita. ZAHRA: Research and Tought Elementary School of Islam Journal, 2(1), 13-23.

Dewi, W. A. F. (2020). Dampak Covid-19 terhadap implementasi pembelajaran daring di Sekolah Dasar. Edukatif: Jurnal Ilmu Pendidikan, 2(1), 55-61.

Dini, J. P. A. U. (2021). Kesiapan Lembaga PAUD dalam Pembelajaran Tatap Muka pada New Normal. Jurnal Obsesi: Jurnal Pendidikan Anak Usia Dini, 5(1), 2158.

Fauzi, I., \& Khusuma, I. H. S. (2020). Teachers' elementary school in online learning of COVID-19 pandemic conditions. Jurnal Iqra': Kajian Ilmu Pendidikan, 5(1), 58-70. 
Fatoni, A. (2020). Wawasan Pendidikan (Pendidikan dan Pendidik). Mida: Jurnal Pendidikan Dasar Islam, 3(1), 65-79.

Gusty, S., Nurmiati, N., Muliana, M., Sulaiman, O. K., Ginantra, N. L. W. S. R., Manuhutu, M. A., ... \& Warella, S. Y. (2020). Belajar Mandiri: Pembelajaran Daring di Tengah Pandemi Covid-19. Yayasan Kita Menulis.

Hamdani, A. R., \& Priatna, A. (2020). Efektifitas implementasi pembelajaran daring (full online) dimasa pandemi Covid-19 pada jenjang Sekolah Dasar di Kabupaten Subang. Didaktik: Jurnal Ilmiah PGSD STKIP Subang, 6(1), 1-9.

Harirah, Z., \& Rizaldi, A. (2020). Merespon Nalar Kebijakan Negara Dalam Menangani Pandemi Covid 19 Di Indonesia. Jurnal Ekonomi dan Kebijakan Publik Indonesia, 7(1).

Hawa, A. M., \& Putra, L. V. (2018). PISA untuk siswa Indonesia. Janacitta, 1(1).

Hewi, L., \& Shaleh, M. (2020). Refleksi hasil PISA (the programme for international student assesment): Upaya perbaikan bertumpu pada pendidikan anak usia dini. Jurnal Golden Age, 4(01), 30-41.

Indriani, R., \& Yemmardotillah, M. (2021). Literasi Digital Bagi Keluarga Milenial Dalam Mendidik Anak Di Era Digital. Continuous Education: Journal of Science and Research, 2(2), 1-13.

Isman, M. (2016). Pembelajaran moda dalam jaringan (moda daring). Seminar Nasional Pendidikan Berkemajuan dan Menggembirakan (The Progressive \& Fun Education Seminar) ke-1. http://hdl.handle.net/11617/7868

Joyo, A. (2018). Gerakan Literasi dalam Pembelajaran Bahasa Indonesia Berbasis Kearifan Lokal Menuju Siswa Berkarakter. Jurnal KIBASP (Kajian Bahasa, Sastra dan Pengajaran), 1(2), 159-170.

Mardliyah, A. A. (2019). Budaya Literasi Sebagai Upaya Peningkatan Keterampilan Berpikir Kritis di Era Industri Revolusi 4.0. In Prosiding SNP2M (Seminar Nasional Penelitian dan Pengabdian Masyarakat) UNIM (No. 1, pp. 171-176).

Masrul, M., Abdillah, L. A., Tasnim, T., Simarmata, J., Daud, D., Sulaiman, O. K., ... \& Faried, A. I. (2020). Pandemik COVID-19: Persoalan dan Refleksi di Indonesia. Yayasan Kita Menulis.

Maulida, D., Ibrahim, M., Thamrin, M., \& Akhwani, A. (2021). Implementasi Pembelajaran Daring melalui Grup Whatsapp pada Siswa Sekolah Dasar. Jurnal Basicedu, 5(5), 3336-3346.

Murray, J. (2021). Literacy is inadequate: young children need literacies. International Journal of Early Years Education, 29(1), 1-5. DOI: 10.1080/09669760.2021.1883816

Numertayasa, I. W., Suardana, I. P. O., \& Adiwijaya, P. A. (2020). The Effect of Literacy Pattern and Mother Tongue on the Language Learning Ability during Learning from Home. In 4th International Conference on Language, Literature, Culture, and Education (ICOLLITE 2020) (pp. 310-315). Atlantis Press.

Napitupulu, R. M. (2020). Dampak pandemi Covid-19 terhadap kepuasan pembelajaran jarak jauh. Jurnal Inovasi Teknologi Pendidikan, 7(1), 23-33.

Naserly, M. K. (2020). Implementasi Zoom, Google Classroom, Dan Whatsapp Group Dalam Mendukung Pembelajaran Daring (Online) Pada Mata Kuliah Bahasa Inggris Lanjut (Studi Kasus Pada 2 Kelas Semester 2, Jurusan Administrasi Bisnis, Fakultas Ekonomi Dan Bisnis, Universitas Bina Sa. Aksara Public, 4(2), 155-165.

Nurkolis, N., \& Muhdi, M. (2020). Keefektivan Kebijakan E-Learning berbasis Sosial Media pada PAUD di Masa Pandemi Covid-19. Jurnal Obsesi: Jurnal Pendidikan Anak Usia Dini, 5(1), 212-228. 
Pakpahan, R. (2016). Faktor-faktor yang memengaruhi capaian literasi matematika siswa Indonesia dalam PISA 2012. Jurnal Pendidikan dan Kebudayaan, 1(3), 331-348.

Pakpahan, R., \& Fitriani, Y. (2020). Analisa pemanfaatan teknologi informasi dalam pembelajaran jarak jauh di tengah pandemi virus corona covid-19. Journal of Information System, Applied, Management, Accounting and Research, 4(2), 30-36.

Prasetyo, T., \& Zulela, M. S. (2021). Proses Pembelajaran Daring Guru Menggunakan Aplikasi Whatsapp Selama Pandemik Covid-19. Jurnal Elementaria Edukasia, 4(1), 138-150.

Opoku-Amankwa, K., \& Brew-Hammond, A. (2011). 'Literacy is the ability to read and write English': defining and developing literacy in basic schools in Ghana. International journal of bilingual education and bilingualism, 14(1), 89-106.

Ratna, P. D. (2021). IMPLEMENTASI PEMBELAJARAN DARING DALAM KETERAMPILAN MENULIS CERITA PADA PESERTA DIDIK KELAS III SDN 3 MERAK BATIN NATAR (Doctoral dissertation, UIN Raden Intan Lampung).

Riadil, I. G., Nuraeni, M., Prakoso, Y. M., \& Yosintha, R. (2020). Persepsi Guru Paud Terhadap Sistem Pembelajaran Daring Melalui Whatsapp Di Masa Pandemi Covid19. PAUDIA: Jurnal Penelitian Dalam Bidang Pendidikan Anak Usia Dini, 9(2), 89-110.

Sanjaya, R. (Ed.). (2020). 21 Refleksi Pembelajaran Daring di Masa Darurat. SCU Knowledge Media.

Subandiyah, H. (2017). Pembelajaran literasi dalam mata pelajaran bahasa indonesia. Paramasastra, 2(1).

Truelove, A. (2020). Literacy. In Gentry culture in late-medieval England. Manchester University Press.

Winarti, E. (2018). Perencanaan manajemen sumber daya manusia lembaga pendidikan. Tarbiyatuna: Jurnal Pendidikan Ilmiah, 3(1), 1-26.

Winarti, A., \& Purwanti, E. Y. (2014). Analisis pengaruh pengeluaran pemerintah bidang pendidikan, kemiskinan, dan PDB terhadap Indeks Pembangunan Manusia di Indonesia Periode 1992-2012 (Doctoral dissertation, Fakultas Ekonomika dan Bisnis).

Yulianto, D., \& Nugraheni, A. S. (2021). Efektivitas Pembelajaran Daring Dalam Pembelajaran Bahasa Indonesia. Decode: Jurnal Pendidikan Teknologi Informasi, 1(1), 33-42. 